\title{
KLASIFIKASI CITRA MAMOGRAFI MENGGUNAKAN JARINGAN SYARAF TIRUAN
}

\section{MAMMOGRAPHYC IMAGES CLASSIFICATION USING ARTIFICIAL NEURAL NETWORK}

\author{
Indah Susilawati
}

\author{
Staf Pengajar Teknik Elektro Universitas Mercu Buana Yogyakarta \\ Jl. Wates Km. 10 Yogyakarta Telp. (0274) 6498211, 6498212 Fax. (0274) 6498213 \\ Email: susilawati.indah@yahoo.co.id
}

\begin{abstract}
There are abnormalities in breast tissue which can be detected by mammogram images analysis. One of those abnormalities is microcalcification. Microcalcifications are small calcium deposits in the breast tissue that can be seen only on a mammogram and can be an indicator of breast cancer. The main objective of this research is to automatically recognize the pattern of two types of breast tissues, i.e. normal tissue and breast tissue which contain microcalcifications in digital mammograms using Matlab software tools.

In this research, pattern recognition is carried out using Artificial Neural Network (ANN), i.e. LVQ (Learning Vector Quantization). The pattern recognition is formulated as a supervised-learning problem and classification was based on sixfeature input given to the ANN. The system recognizes the pattern in three steps. Firstly, a tophat transformation is applied on the images, and then features of the images are extracted based on images pixel values. Finally, image classification is carried out in recognizing the pattern. The research uses 26 digital mammograms, consist of 16 normal mammograms and 10 mammograms which contain microcalcifications.

The results show that the $L V Q$ best performance in recognizing the pattern is $97 \%$, using learning rate and decrement of learning rate equal to 0.1.
\end{abstract}

Keywords: mammograms, microcalcification, pattern recognition, $L V Q$.

\section{PENDAHULUAN}

Seorang dokter atau ahli radiologi menggunakan citra mamografi untuk mengetahui adanya abnormalitas pada jaringan payudara. Citra mamografi dapat dihasilkan dengan pencitraan sinar $X$ menggunakan mesin mamografi (mammogram machine). Analisis seperti ini membutuhkan keahlian dan pengalaman, dengan kata lain hasil analisis bersifat subjektif.
Analisis jenis lain, misalnya analisis berbantuan komputer diharapkan dapat bersifat lebih objektif. Analisis jenis yang terakhir ini diharapkan dapat dibangun sebagai alat bantu bagi dokter atau ahli radiologi dalam melakukan diagnosa dan bukan menggantikan peran dokter atau ahli radiologi sepenuhnya. 
Diagnosis kanker payudara dapat dilakukan menggunakan pemrograman linear, dan diagnosis berdasarkan metode pembelajaran merupakan suatu obyek penelitian yang klasifikasi dan pengenalan pola. Metode ini menawarkan kemampuan untuk membedakan objek menjadi beberapa kelas berdasarkan ciri yang ada pada masingmasing kelas atau kategori obyek tersebut [Duda, 2000].

Pada penelitian ini dilakukan klasifikasi citra mamografi menjadi dua kelas, yaitu citra normal dan citra bermikrokalsifikasi. Mikrokalsifikasi merupakan deposit atau timbunan kalsium pada jaringan payudara dan biasanya menjadi tanda-tanda awal perubahan ke arah kanker [El-Naqa, 2002]. Ciri-ciri yang digunakan dalam proses klasifikasi adalah ciri-ciri statistik yang diperoleh dari nilainilai piksel citra.

\section{METODOLOGI PENELITIAN}

\section{Bahan Penelitian}

Bahan penelitian diperoleh dari basis data MIAS (Mammographic Image Analysis Society). Citra yang tersedia berupa citra aras keabuan 8 bit berukuran 1024 x 1024 piksel dengan ukuran piksel 200 mikron. Pada penelitian ini digunakan 16 citra mamografi normal dan 10 citra mamografi bermikrokalsifikasi.

\section{Metodologi}

Langkah-langkah yang dilakukan dalam penelitian ini diperlihatkan pada Gambar 1 [Duda, 2000].

Sampling dilakukan untuk mengambil sampel-sampel citra dari citra mamografi normal (selanjutnya disebut citra normal) dan citra mamografi yang mengandung mikrokalsifikasi (selanjutnya disebut dengan citra bermikrokalsifikasi). Dalam penelitian ini diambil 64 sampel citra normal dan 34 sampel citra bermikrokalsifikasi. Semua sampel berukuran 40 x 40 piksel. sangat menjanjikan [Mangasarian, 1995]. Jaringan Syaraf Tiruan merupakan suatu metode pembelajaran yang dapat digunakan untuk

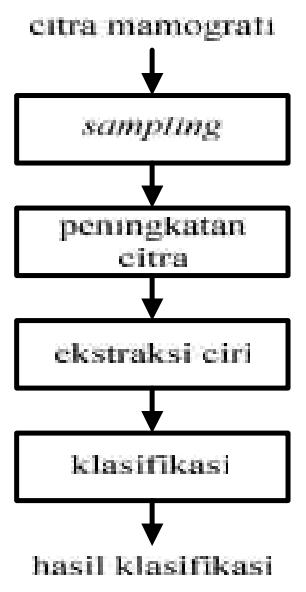

Gambar 1. Diagram blok langkah penelitian

Citra mamografi seringkali mempunyai kontras yang kurang baik. Untuk mengatasinya maka dalam penelitian ini dilakukan peningkatan citra menggunakan transformasi tophat. Untuk kepentingan transformasi tersebut digunakan persamaan berikut.

$$
\operatorname{TopHat}(\mathrm{A}, \mathrm{B})=\mathrm{A}-(\mathrm{A} \circ \mathrm{B})=\mathrm{A}-\max _{\mathrm{B}}\left(\min _{\mathrm{B}}(\mathrm{A})\right)
$$

Dengan A adalah objek yang akan ditransformasikan, B adalah elemen penstruktur (structuring element), notasi ○ menyatakan operasi pembukaan (opening) untuk objek terang dengan latar belakang gelap. Matlab memberikan beberapa pilihan bentuk elemen penstruktur, di antaranya berbentuk disk, line, dan lain-lain. Pada penelitian ini digunakan elemen penstruktur berbentuk disk karena secara visual titiktitik deposit kalsium atau mikrokalsifikasi biasanya cenderung berbentuk bulat. Secara umum transformasi bertujuan untuk meningkatkan kontras citra sehingga ciriciri yang membedakan antara citra normal dan citra dengan mikrokalsifikasi akan lebih menonjol.

Langkah selanjutnya adalah proses ekstraksi ciri citra yang sebelumnya telah melalui proses peningkatan citra. Dalam Elektron: Vol. 1 No. 2, Edisi: Desember 2009 
penelitian ini diekstrak enam ciri citra berdasarkan nilai-nilai piksel citra sampel [Jain, 1989]. Keenam ciri tersebut adalah rerata, varians, standar deviasi (disingkat std), entropi, beda antara nilai piksel maksimum dan nilai minimun (selanjutnya disebut dengan istilah beda1), serta beda antara nilai piksel maksimum dan nilai reratanya (selanjutnya disebut dengan istilah beda2). Hasil ekstraksi ciri akan menjadi masukan pengklasifikasi (classifier).

Pada penelitian ini digunakan Jaringan Syaraf Tiruan, yaitu Learning Vector Quantization (LVQ), sebagai pengklasifikasi. LVQ merupakan jenis Jaringan Syaraf Tiruan yang bekerja berdasarkan pembelajaran kompetitif dan termasuk dalam kategori pembelajaran terbimbing atau supervised [Sri Widodo, 2005; Siang, 2005]. Arsitektur LVQ yang akan digunakan pada penelitian ini diperlihatkan pada Gambar 2.

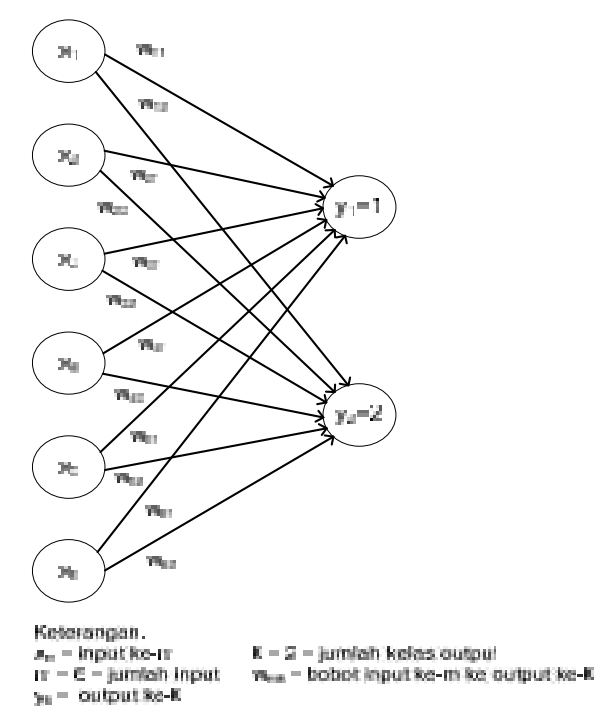

Gambar 2. Arsitektur LVQ yang digunakan

Masukan jaringan LVQ, yaitu $\mathrm{x}_{1}$ sampai dengan $\mathrm{x}_{6}$, adalah vektor ciri yang telah diekstrak pada langkah sebelumnya. Bobot $\mathrm{w}_{\mathrm{mk}}$ adalah bobot masukan ciri ke-m ke keluaran ke-k. Keluaran jaringan LVQ berupa kelas citra (ditentukan kelas 1 untuk citra normal dan kelas 2 untuk citra bermikrokalsifikasi). Bobot awal jaringan
LVQ ditentukan secara acak dari hasil ekstraksi ciri sampel citra.

Berikut adalah algoritma pelatihan jaringan LVQ yang digunakan dalam penelitian ini [Kusumadewi, 2004]. Notasinotasi yang digunakan adalah:

$\begin{array}{lll}\mathrm{x} & : & \text { vektor pelatihan }\left(\mathrm{x}_{1}, \mathrm{x}_{2}, \ldots, \mathrm{x}_{\mathrm{m}}\right) \\ \mathrm{T} & : & \text { kelas atau kategori vektor pelatihan } \\ & \text { yang sebenarnya } \\ \mathrm{w}_{\mathrm{j}}: & \text { vektor bobot untuk unit output ke- } \mathrm{j} \\ & \left(\mathrm{w}_{1 \mathrm{j}}, \mathrm{w}_{2 \mathrm{j}}, \ldots, \mathrm{w}_{\mathrm{mj}}\right) \\ \mathrm{C}_{\mathrm{j}}: & \begin{array}{l}\text { kelas atau kategori yang } \\ \text { direpresentasikan oleh unit output } \\ \text { ke-j } \\ \end{array} \\ & \begin{array}{l}\text { jarak Euclidean antara vektor } \\ \text { input dan vektor bobot untuk unit } \\ \text { output ke- } \mathrm{j}-\mathrm{w}_{\mathrm{j}} \|\end{array}\end{array}$

Langkah 0 Inisialisasi vektor-vektor bobot awal dan laju pembelajaran $\alpha(0)$.

Langkah 1 Jika kondisi berhenti salah, lakukan langkah $2-6$.

Langkah 2 Untuk setiap vektor input pelatihan $\mathrm{x}$, lakukan langkah 3 4.

Langkah 3 Tentukan $\mathrm{J}$ sedemikian rupa sehingga $\left\|\mathrm{x}-\mathrm{w}_{\mathrm{j}}\right\|$ minimum.

Langkah 4 Perbarui $w_{j}$ dengan ketentuan sebagai berikut:

Jika $\mathrm{T}=\mathrm{C}_{\mathrm{j}}$ maka $\mathrm{w}_{\mathrm{j}}(\mathrm{b})=\mathrm{w}_{\mathrm{j}}(\mathrm{l})+\alpha\left[\mathrm{x}-\mathrm{w}_{\mathrm{j}}(\mathrm{l})\right]$

Jika $\mathrm{T} \neq \mathrm{C}_{\mathrm{j}}$ maka

$$
\mathrm{w}_{\mathrm{j}}(\mathrm{b})=\mathrm{w}_{\mathrm{j}}(\mathrm{l})-\alpha\left[\mathrm{x}-\mathrm{w}_{\mathrm{j}}(\mathrm{l})\right]
$$

Langkah 5 Kurangi laju pembelajaran.

Langkah 6 Tes kondisi berhenti. Kondisi berhenti dapat berupa jumlah iterasi tertentu yang tetap (yaitu eksekusi langkah 1) atau laju pembelajaran mencapai nilai yang cukup kecil.

\section{HASIL DAN PEMBAHASAN}

\section{Hasil Penelitian}

Sampling citra baik citra normal maupun citra bermikrokalsifikasi dilakukan dari data yang diperoleh dari basis data MIAS. Pada Gambar 3 diperlihatkan satu contoh hasil sampling citra normal (kelas 1) yang akan digunakan dalam penelitian ini. Sedangkan pada Gambar 4 diperlihatkan 
satu contoh hasil sampling untuk citra bermikrokalsifikasi (kelas 2).

Gambar 3. Contoh hasil sampling citra normal

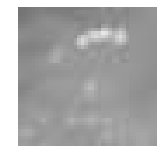

Gambar 4. Contoh hasil sampling citra bermikrokalsifikasi

Gambar 5 memperlihatkan hasil transformasi tophat untuk sampel citra normal (kelas 1) Gambar 3. Sedangkan pada Gambar 5 diperlihatkan hasil transformasi tophat untuk sampel citra bermikrokalsifikasi (kelas 2) pada Gambar 4.

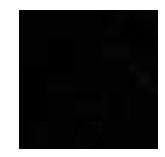

Gambar 5. Hasil perentangan kontras citra normal pada Gambar 3

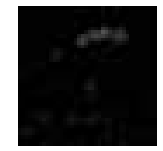

Gambar 6. Hasil perentangan kontras citra bermikrokalsifikasi pada Gambar 4

Jangkauan nilai hasil ekstraksi ciri pada semua sampel citra untuk citra normal dan citra bermikrokalsifikasi ditampilkan pada Tabel 1 dan Tabel 2.

Tabel 1. Jangkauan nilai ciri (tanpa transformasi tophat)

\begin{tabular}{lcc}
\hline \multirow{1}{*}{ Ciri } & \multicolumn{2}{c}{ Jangkauan Nilai } \\
\cline { 2 - 3 } & Citra Normal & $\begin{array}{c}\text { Citra } \\
\text { bermikrokalsifikasi }\end{array}$ \\
Rerata & $0,0050-$ & $96,6319-181,0606$ \\
Varians & 219,5988 & \\
Std & $0,0040-1779,8$ & $39,8339-391,5422$ \\
Entropi & $0,0076-7,0703$ & $6,3114-19,7874$ \\
Bedaan1 & $8-167$ & $4,5959-6,1755$ \\
\end{tabular}

Bedaan2 $\quad 6,4013-63,8131 \quad 26,4419-73,1188$

Tabel 2. Jangkauan nilai ciri (dengan transformasi tophat)

\begin{tabular}{lcc}
\hline \multirow{1}{*}{ Ciri } & \multicolumn{2}{c}{ Jangkauan Nilai } \\
\cline { 2 - 3 } & Citra Normal & $\begin{array}{c}\text { Citra } \\
\text { bermikrokalsifikasi }\end{array}$ \\
Rerata & $0,0050-2,8169$ & $1,8425-3,8706$ \\
Varians & $0,0040-$ & $4,3215-69,7926$ \\
& 10,3858 & \\
Std & $0,1999-3,2227$ & $2,0788-8,3542$ \\
Entropi & $0,0076-7,0703$ & $4,5707-6,1755$ \\
Bedaan1 & $3-20$ & $16-72$ \\
Bedaan2 & $2,6981-$ & $13,7125-68,1294$ \\
& 17,6806 & \\
\hline
\end{tabular}

Jaringan LVQ yang dibangun akan dilatih menggunakan data ciri dari 98 sampel yang ada, kemudian jaringan yang telah terlatih diuji menggunakan data yang sama. Tabel 3 hingga Tabel 6 memperlihatkan hasil klasifikasi selengkapnya.

\section{Pembahasan}

Sampling citra bertujuan mengambil sampel-sampel citra yang akan digunakan untuk klasifikasi citra. Sampel citra normal yang digunakan adalah sebanyak 64 sampel, diambil secara acak dari citra mamografi normal. Sampel citra ini dikategorikan sebagai citra kelas 1 .

Sampel citra bermikrokalsifikasi yang digunakan berjumlah 34 sampel, diambil dari citra bermikrokalsifikasi. Pengambilan sampel citra bermikrokalsifikasi dilakukan dengan memperhatikan letak atau posisi mikrokalsifikasi, informasi ini diperoleh dari basis data MIAS. Sampel citra bermikrokalsifikasi dikategorikan sebagai citra kelas 2.

Tabel 3. Hasil pengenalan pola (tanpa transformasi tophat, dec $\alpha=0,1$, $\min \alpha=10^{-4}$, maxepoch $=100$ )

\begin{tabular}{c|c|c|c}
\hline$\alpha$ & $\begin{array}{c}\text { Tingkat Pengenalan } \\
\text { Rata-rata (\%) }\end{array}$ & $\begin{array}{c}\text { Jumlah } \\
\text { Epoch }\end{array}$ & $\begin{array}{c}\alpha \\
\text { Minimum }\end{array}$ \\
\hline 0,1 & 50 & 66 & $9,6 \times 10^{-5}$ \\
0,2 & 50 & 73 & $9,1 \times 10^{-5}$ \\
0,3 & 50 & 76 & $10 \times 10^{-5}$ \\
0,4 & 50 & 79 & $9,7 \times 10^{-5}$ \\
0,5 & 50 & 81 & $9,8 \times 10^{-5}$ \\
0,6 & 50 & 83 & $9,6 \times 10^{-5}$ \\
0,7 & 50 & 85 & $9,0 \times 10^{-5}$ \\
0,8 & 50 & 86 & $9,3 \times 10^{-5}$ \\
\hline
\end{tabular}

Elektron: Vol. 1 No. 2, Edisi: Desember 2009 


\begin{tabular}{cccc}
\hline 0,9 & 50 & 87 & $9,4 \times 10^{-5}$ \\
1 & 50 & 88 & $9,4 \times 10^{-5}$ \\
\hline
\end{tabular}

Tabel 4. Hasil pengenalan pola (tanpa transformasi tophat, dec $\alpha=0,5$, $\min \alpha=10^{-4}$, maxepoch $=100$ )

\begin{tabular}{cccc}
\hline$\alpha$ & $\begin{array}{c}\text { Tingkat Pengenalan } \\
\text { Rata-rata (\%) }\end{array}$ & $\begin{array}{c}\text { Jumlah } \\
\text { Epoch }\end{array}$ & $\begin{array}{c}\alpha \\
\text { Minimum }\end{array}$ \\
\hline 0,1 & 59 & 10 & $9,8 \times 10^{-5}$ \\
0,2 & 58 & 11 & $9,8 \times 10^{-5}$ \\
0,3 & 50 & 12 & $7,3 \times 10^{-5}$ \\
0,4 & 50 & 12 & $9,8 \times 10^{-5}$ \\
0,5 & 50 & 13 & $6,1 \times 10^{-5}$ \\
0,6 & 50 & 13 & $7,3 \times 10^{-5}$ \\
0,7 & 50 & 13 & $8,5 \times 10^{-5}$ \\
0,8 & 50 & 13 & $9,8 \times 10^{-5}$ \\
0,9 & 50 & 14 & $5,5 \times 10^{-5}$ \\
1 & 50 & 14 & $6,1 \times 10^{-5}$ \\
\hline
\end{tabular}

Tabel 5. Hasil pengenalan pola (dengan transformasi tophat, dec $\alpha=0,1$, $\min \alpha=10^{-4}, \operatorname{maxepoch}=100$ )

\begin{tabular}{cccc}
$\alpha$ & $\begin{array}{c}\text { Tingkat Pengenalan } \\
\text { Rata-rata (\%) }\end{array}$ & $\begin{array}{c}\text { Jumlah } \\
\text { Epoch }\end{array}$ & $\begin{array}{c}\alpha \\
\text { Minimum }\end{array}$ \\
\hline 0,1 & 97 & 66 & $9,6 \times 10^{-5}$ \\
0,2 & 97 & 73 & $9,1 \times 10^{-5}$ \\
0,3 & 97 & 76 & $10 \times 10^{-5}$ \\
0,4 & 97 & 79 & $9,7 \times 10^{-5}$ \\
0,5 & 97 & 81 & $9,8 \times 10^{-5}$ \\
0,6 & 97 & 83 & $9,6 \times 10^{-5}$ \\
0,7 & 97 & 85 & $9,0 \times 10^{-5}$ \\
0,8 & 50 & 86 & $9,3 \times 10^{-5}$ \\
0,9 & 50 & 87 & $9,4 \times 10^{-5}$ \\
1 & 97 & 88 & $9,4 \times 10^{-5}$ \\
\hline
\end{tabular}

Tabel 6. Hasil pengenalan pola (dengan transformasi tophat, dec $\alpha=0,5$, $\min \alpha=10^{-4}$, maxepoch $=100$ )

\begin{tabular}{cccc}
$\alpha$ & $\begin{array}{c}\text { Tingkat Pengenalan } \\
\text { Rata-rata (\%) }\end{array}$ & $\begin{array}{c}\text { Jumlah } \\
\text { Epoch }\end{array}$ & $\begin{array}{c}\alpha \\
\text { Minimum }\end{array}$ \\
\hline 0,1 & 97 & 10 & $9,8 \times 10^{-5}$ \\
0,2 & 97 & 11 & $9,8 \times 10^{-5}$ \\
0,3 & 97 & 12 & $7,3 \times 10^{-5}$ \\
0,4 & 97 & 12 & $9,8 \times 10^{-5}$ \\
0,5 & 97 & 13 & $6,1 \times 10^{-5}$ \\
0,6 & 97 & 13 & $7,3 \times 10^{-5}$ \\
0,7 & 97 & 13 & $8,5 \times 10^{-5}$ \\
0,8 & 97 & 13 & $9,8 \times 10^{-5}$ \\
0,9 & 97 & 14 & $5,5 \times 10^{-5}$ \\
1 & 97 & 14 & $6,1 \times 10^{-5}$ \\
\hline
\end{tabular}

Jumlah sampel citra normal diambil kira-kira dua kali lipat jumlah sampel citra bermikrokalsifikasi. Hal ini dilakukan dengan alasan bahwa citra mamografi normal jauh lebih bervariasi daripada citra bermikrokalsifikasi, misalnya oleh karena sifat jaringan, adanya saluran air susu ibu, pembuluh darah, dan lain-lain [Sheshadri, 2006; Liu, 1998].
Untuk kepentingan peningkatan citra digunakan transformasi tophat. Langkah ini dilakukan karena citra mamografi seringkali merupakan citra dengan kontras yang kurang baik. Kontras yang kurang baik ini dapat dipengaruhi oleh proses pencitraan itu sendiri misalnya karena penggunaan dosis sinar $\mathrm{X}$ yang kurang sesuai atau karena pengaruh sifat jaringan yang bersangkutan [Yaffe, 1995].

Pada Gambar 5 dan Gambar 6 diperlihatkan sampel citra yang telah dikenakan transformasi tophat, masingmasing untuk citra normal dan citra bermikrokalsifikasi. Perbaikan kontras citra ini juga akan lebih tampak jika dibandingkan histogram citranya, yaitu histogram citra sebelum dan sesudah proses transformasi perentangan kontras.

Ekstraksi ciri pada sampel-sampel citra yang telah dikenai transformasi tophat menghasilkan ciri-ciri yang jangkauannya masing-masing diperlihatkan pada Tabel 1 dan Tabel 2. Setiap sampel citra akan menghasilkan kombinasi enam ciri, yang akan membentuk satu vektor ciri sehingga secara keseluruhan terdapat 98 vektor ciri yang diekstrak dari 98 sampel citra yang digunakan. Vektor ciri inilah yang digunakan sebagai masukan jaringan pengklasifikasi LVQ.

Dalam penelitian ini dilakukan pelatihan dan pengujian jaringan pengklasifikasi dengan data yang sama. Klasifikasi dilakukan dengan berbagai kombinasi parameter jaringan, yaitu dengan berbagai nilai laju pelatihan $(\alpha)$ dan penurunan laju pelatihan $(\operatorname{dec} \alpha)$. Tanpa transformasi tophat, jaringan LVQ hampir tidak mengenali jaringan bermikrokalsifikasi sebagai kelas 2 (dalam hal ini jaringan bermikrokalsifikasi dikenali sebagai jaringan normal atau kelas 1), atau tingkat pengenalan rata-rata $50 \%$. Jaringan mampu mengenali kedua jenis citra saat digunakan nilai $\alpha=0,1$ dan $\alpha=0,2$ (nilai $\operatorname{dec} \alpha=0,5)$, yaitu setinggi $59 \%$. Dengan demikian dapat disimpulkan bahwa jika menggunakan ciri-ciri yang diekstrak dari 
sampel asli, jaringan LVQ hanya mampu menampilkan kinerja pengenalan pola tertinggi $59 \%$.

Berdasarkan hasil pengenalan pola dengan masukan ciri-ciri sampel yang dikenai transformasi tophat pada Tabel 5dan Tabel 6, diperoleh pengenalan tertinggi $97 \%$. Kinerja pengenalan dapat dikatakan cukup stabil kecuali saat digunakan $\operatorname{dec} \alpha=0,1$ dengan nilai $\alpha$ sebesar 0,8 dan 0,9. Pada kedua nilai kombinasi dec $\alpha$ dan $\alpha$ ini hanya diperoleh kinerja pengenalan $50 \%$ yang berarti jaringan LVQ tidak mampu mengenali jaringan dengan mikrokalsifikasi; semua sampel dikenali sebagai jaringan normal.

Berdasarkan kedua tabel juga diketahui bahwa tingkat pengenalan setinggi 97\% dicapai hampir pada seluruh kombinasi dec $\alpha$ dan $\alpha$ kecuali pada saat digunakan $\operatorname{dec} \alpha=0,1$ dengan nilai $\alpha$ sebesar 0,8 dan 0,9. Untuk menentukan kombinasi dec $\alpha$ dan $\alpha$ terbaik dapat ditentukan dengan memperhatikan jumlah epoch yang diperlukan untuk mencapai kinerja pengenalan tersebut. Jumlah epoch untuk keempat tabel di atas disajikan kembali dalam bentuk grafik pada Gambar 7.

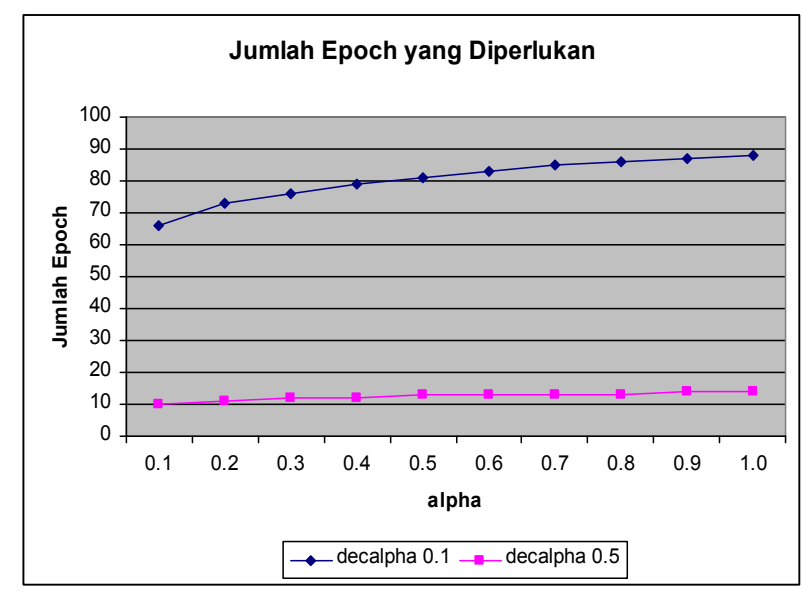

\section{Gambar 7. Grafis perbandingan hasil pengenalan pola}

Jumlah epoch terkecil yang diperlukan untuk proses pengenalan pola pada penelitian ini adalah 10 epoch, dicapai saat digunakan $\operatorname{dec} \alpha=0.1$ dan $\alpha=0.1$. Pada kombinasi dec $\alpha$ dan $\alpha$ tersebut, jaringan LVQ menghasilkan bobot akhir jaringan sebagai berikut.

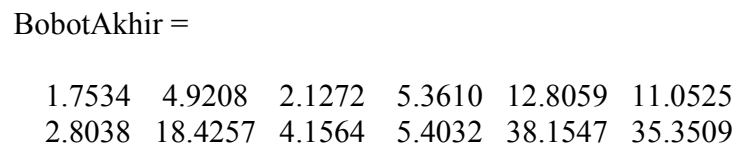

Berdasarkan hasil-hasil di atas, maka jaringan LVQ yang direkomendasikan untuk digunakan untuk pengenalan pola jaringan normal dan jaringan dengan mikrokalsifikasi pada citra mamografi digital adalah jaringan LVQ yang telah dilatih menggunakan dec $\alpha=0.1$ dan $\alpha=$ 0.1. Kesimpulan ini ditentukan dengan memperhatikan jumlah epoch yang diperlukan untuk pelatihan jaringan LVQ, yaitu 10 epoch yang merupakan jumlah epoch terkecil dalam penelitian ini. Jumlah epoch yang kecil berarti waktu yang lebih singkat dan juga memungkinkan terhindarnya overlearning (akibat overfitting) selama proses pelatihan jaringan LVQ.

\section{SIMPULAN DAN SARAN}

\section{Simpulan}

Berdasarkan hasil penelitian dan pembahasan pada bab sebelumnya, dapat ditarik beberapa kesimpulan sebagai berikut.

1. Jaringan LVQ dapat digunakan untuk proses pengenalan pola jaringan normal dan jaringan dengan mikrokalsifikasi pada citra mamografi digital, dengan masukan berupa ciri-ciri yang diekstrak berdasarkan nilai piksel citra yaitu rerata, varians, standar deviasi, entropi, beda nilai piksel minimum dan maksimum, serta beda nilai piksel maksimum dengan reratanya.

2. Transformasi tophat pada citra mampu meningkatkan kinerja pengenalan pola oleh jaringan LVQ. Kinerja pengenalan pola tertinggi tanpa transformasi tophat hanya mencapai 59\%, sedangkan 
dengan pra-pengolahan berupa transformasi tophat kinerja pengenalan pola oleh jaringan LVQ mencapai 97\%.

\section{Saran}

Berdasarkan hasil penelitian dan pembahasan serta simpulan, maka dapat disarankan untuk pengembangan penelitian ini. Mengupayakan kinerja pengenalan pola oleh jaringan LVQ yang lebih tinggi lagi dengan cara mengekstrak lebih banyak ciri dari citra mamografi untuk selanjutnya digunakan sebagai masukan jaringan LVQ.

1. Mengupayakan kinerja pengenalan pola yang lebih tinggi lagi menggunakan metode klasifikasi yang lain, misalnya menggunakan SVM (Support Vector Machines).

2. Menggunakan jaringan LVQ terlatih yang telah dihasilkan pada penelitian ini untuk mendeteksi letak jaringan yang mengandung mikrokalsifikasi pada citra mamografi digital.

\section{DAFTAR PUSTAKA}

El-Naqa, Issam, dkk, 2002, Support Vector Machine Learning for Detection of Microcalcifications in Mammograms, Dept. Of Electrical and Computer Engineering, Illinois Institute of Technology.

Duda, R.O., Harl, P.E., Stork, D.G., 2000, Pattern Classification, Second Edition, John Wiley \& Sons, Inc.

Haykin, Simon,. 1994, Neural Network a Comprehensive Foundation, Macmillan College Publishing Company.

Jain, Anil K., 1989, Fundamental of Digital Image Processing, Prentice Hall International, Inc. Singapore.

Kusumadewi, Sri., 2004, Membangun Jaringan Syaraf Tiruan Menggunakan
Matlab dan Excel Link, Graha Ilmu, Yogyakarta.

Liu, Sheng., Babbs, Charles F., dan Delp, Edward J., 1998, Normal Mammogram Analysis and Recognition, Purdue University, Indiana.

Mangasarian, O.L., 1995, Breast Cancer Diagnosis and Prognosis via Linear Programming, Oper. Res., 43: 570577.

Munir, R., 2004, Pengolahan Citra Digital dengan Pendekatan Algoritmik, Informatika Bandung.

Sheshadri, H.S. dan Kandaswamy, A., 2006, Computer Aided Decision System for Early Detection of Breast Cancer, Indian J Med Res 124, pp $149-154$.

Siang, J.J., 2005, Jaringan Syaraf Tiruan dan Pemrogramannya Menggunakan Matlab, Penerbit Andi, Yogyakarta.

Sri Widodo, Thomas, 2005, Sistem Neuro Fuzzy untuk Pengolahan Informasi, Pemodelan, dan Kendali, Graha Ilmu, Yogyakarta.

Yaffe, Martin J,. 1995, Mammography, Biomedical Engineering Handbook, IEEE Press.

http://www.imaginis.com/breasthealth /statistics.asp, download tanggal 15 Mei 2008 pukul 13.42 WIB.

http://peipa.essex.ac.uk/ipa/pix/mias, download tanggal 27 Desember 2007 pukul 12.22 WIB.

, http://www.ph.tn.tudelft.nl/Courses/ FIP/noframes/fip download tanggal 24 April 2008 pukul 19.39 WIB. 